\title{
The Outsourcing Debate: Theories and Findings 1
}

\begin{tabular}{|c|c|c|}
\hline $\begin{array}{c}\text { Stewart R. Clegg } \\
\text { Professor, } \\
\text { School of Management } \\
\text { The University of Technology, } \\
\text { Sydney } \\
\text { PO Box 123, Broadway NSW } \\
\text { 2007, Australia } \\
\text { Tel: } 61295143934 \\
\text { Fax: } 61295143312 \\
\text { s.clegg@uts.edu.au } \\
\text { Visiting Professor at Aston } \\
\text { Business School (UK); } \\
\text { The University of Maastricht } \\
\text { Faculty of Business, } \\
\text { Visiting Professor and } \\
\text { International Fellow in Discourse } \\
\text { and Management Theory, Centre } \\
\text { of Comparative Social Studies, } \\
\text { Free University of Amsterdam }\end{array}$ & $\begin{array}{c}\text { Steve Burdon } \\
\text { Visiting Professor, } \\
\text { School of Management } \\
\text { The University of Technology, } \\
\text { Sydney } \\
\text { PO Box 123, Broadway NSW } \\
\text { 2007, Australia } \\
\text { Tel: 6129514 } 3072 \\
\text { Fax: } 61295143371 \\
\text { steve.burdon@uts.edu.au }\end{array}$ & $\begin{array}{c}\text { Natalia Nikolova } \\
\text { Associate Lecturer, } \\
\text { School of Management } \\
\text { The University of Technology, } \\
\text { Sydney } \\
\text { PO Box 123, Broadway NSW } \\
\text { 2007, Australia } \\
\text { Tel: } 61295143645 \\
\text { Fax: } 61295143602 \\
\text { natalia.nikolova@uts.edu.au }\end{array}$ \\
\hline
\end{tabular}

This research is supported by a Linkage Grant from the Australian Research Council, LP0348749, which, in turn, was facilitated by a UTS Industry Seeding Grant. In 2003-2004 we received funding from the Australian Research Council Linkage scheme to conduct research into the industry. The linkage scheme encourages researchers to form industry partnerships for the research process, in order to develop research outcomes that are of industry relevance. It is stressed in the ARC guidelines that the research should not be a consultancy. One of the big-five industry companies, Transfield, was our industry partner. We have already acknowledged the support of the company and its executives. We should stress, however, that our research was conducted independently of the company and was in no way anything other than a dedicated research project. The authors would like to thank Transfield and Boston Consulting Group for their contribution to this study. They also would like to acknowledge the assistance of Rachael Weiss in helping to design the study and Rosie Stilin, for research assistance, as well as the participants in both the quantitative and qualitative study, and the helpful comments of Fons Naus, Robert Roe, John Sillince, Carl Rhodes, Tyrone Pitsis, Martin Kornberger and Robert van Krieken on earlier drafts.

\footnotetext{
1 Sometimes reviewers really do improve papers; sometimes they are a pest. We are happy to report that on this occasion the reviewers were extremely well-focused and helpful, and all of their suggestions served to improve the clarity of the paper. Of course, any liability for its remaining shortcomings is ours alone.
} 


\title{
The Outsourcing Debate: Theories and Findings
}

\begin{abstract}
This paper addresses the issue of services outsourcing by looking at both theoretical and empirical arguments. Previous debates have often concentrated on the motives for adopting the practice rather than the outcomes. These various themes can be discussed under the twin concepts of the cost and efficiency argument and the fashion and isomorphism approach. Our research provides strong evidence to support the cost efficiency argument. On average, significant cost advantages were sought and delivered, as well as improvements in service levels and systems. Many organisations in the current environment in Australia look at outsourcing not only as a method of increasing efficiency but also as gaining competitive advantage through harnessing the superior specialist skills and experience of the outsourcing provider who takes someone's back office function and transforms them into their front office. A 10\% net cost saving was considered necessary by an organisation before embarking on an organisational change that was disruptive and in some cases involved downside risks. Even if other efficiency gains such as service levels or systems improvements were required, so were $10 \%+$ cost savings. A number of the organisations thought their skills in managing outsourcing had improved considerably such that they were in a position to move from a client/server relationship to a partnership model (i.e. an alliance).
\end{abstract}

Keywords: outsourcing, costs savings, qualitative and quantitative research 


\section{The Outsourcing Debate: Theories and Findings}

\section{INTRODUCTION}

The initial decision to move from an in-house service to an outsourcing provider is major. In the vast majority of cases, when organisations move a business function from intraorganisational to third party control, significant efficiency gains are expected by focusing "time, effort and capital on value-creating activities that yield a competitive advantage, an improved overall performance, and security for the organisations' long-term survival” (Hunter \& Cooksey, 2004: 27).

Outsourcing is not a new phenomenon: in major production industries such as automotives, the outsourcing of initially non-core and latterly core functions and services has been progressively used since the 1930s (Macaulay, 1966). However, services outsourcing, although common for some time in specialist areas such as advertising and legal services, increased dramatically from the mid-1990s. The outsourcing of sectors such as IT and Telecommunications and Business Processing occurred with the dawning of advanced digital telecommunications services that facilitated the availability of this option. The imperative to outsource - as distinct from the opportunity to do so - was a result of other dynamics of the digital age; primarily globalisation and increased competition, leading to a continual need to improve efficiency from productivity and to increase service levels. Thus, vertically integrated services were no longer seen as the best organisational arrangements for gaining competitive advantage. The idea of extending the organisation's capabilities, whether core or non-core, to a third party, is confirmed in recent research in the area by Gottfredson, Puryear and Phillips (2005). Gottfredson et al.'s (2005) framework suggests that competitive advantage can be gained by optimising uniqueness of function versus the proprietary nature of the organisations' capabilities.

\section{POSITIONS ON OUTSOURCING INSTITUTIONAL FASHION OR COST EFFICIENCIES?}

Critics of outsourcing suggest that "contracting out might be no more than a temporary enthusiasm, a fad ..." (Savas, 1993: 43). Savas is not alone in this view: Walker and Walker (2000: 156) also suggest that outsourcing may be a modish fad, something that organisations might claim to do for efficiency reasons but which in practice deliver far less efficiency than is often claimed. “...the claim '20 per cent savings from contracting out' became part of the repertoire of catchphrases favoured by privatisation advocates”. A recent study that examines the impact of outsourcing on both organisation and employees in large Australian organisations in all industrial sectors covering public and private organisations supports the view that outsourcing has been promoted as a fashionable movement (Benson \& Littler, 2002). One of Benson \& Littler's findings was that outsourcing did not have a significant impact on performance, compared to other forms of restructuring. Also, in the context of IT, Fischli (1996) wondered, whether outsourcing really was a new management tool or merely a fad; a question reiterated a number of times since (Hunter \& Gates, 1998; Lonsdale \& Cox, 2000). Clearly, the development of digitalization has offered considerable opportunities for outsourcing more generally (Clarke and Clegg 1998). However, in this study, we focus on more material aspects of organizing, notably, the servicing of plant and equipment, which cannot be digitally outsourced but have to be serviced in situ.

It is evident that the critics of outsourcing as a fashion base their arguments more or less implicitly on institutional theory (Abrahamson, 1991). For instance, Walker and Walker (2000) and Quiggin (1994, 1996) make strong claims that outsourcing in the public sector is the result of public organisations seeking to copy private companies to demonstrate 
conformity with modern management thought and to show that they are at least trying to improve their services, rather than the result of evidence on the efficiency gains of contracting out. Quiggin (1996: 49) argues "some moves towards contracting out of public sector activities may be seen primarily as bringing the public sector into line with the standard practices of large private business enterprises”, arguing, implicitly, a case for mimetic isomorphism (DiMaggio \& Powell, 1983). Hodge (1999: 466) pointed out that in the public sector 'the drive to contract out government services was often heavily founded on the privatization ideology'. Walker and Walker (2000: 153) claim, referring to the reform of the public sector, "it was simply assumed that the private sector was more efficient than the public sector, so that outsourcing would mean cost-savings”. They further state that "advocates of 'contracting out' rely to a large extent on rhetoric about the alleged need for smaller government, and for competition in service delivery” (Walker \& Walker, 2000: 148).

From an institutional perspective, efficiency arguments are of less consequence than those that stress mimetic isomorphism, which is adoption based on mimesis or copying (DiMaggio \& Powell, 1983). Public sector organisations favour outsourcing practice in part because they became widely institutionalised as a part of the 'privatization package' premised on the contracting out of government services. The Industry Commission estimated that the value of services contracted out by Australian public sector agencies exceeded 13 billion AUD a year by the mid-1990s (Rimmer, 1998). Thus, it is clear that contracting out has become a significant public sector phenomenon in Australia.

Although it is undoubtedly fashionable there is a substantive ignorance of what are the specifics of outsourcing: top management teams are often unsure about what it entails (Rothery \& Roberts, 1995). Such relative lack of understanding might be a reason for the significant rates of failure to deliver benefits in the terms which, phenomenologically, the contract managers anticipated, as reported by Doig, Ritter, Speckhals, and Woodson (2001), and the widespread dissatisfaction reported from Dunn \& Bradstreet surveys of outsourcing initiatives. In line with the expectations of institutional theory (DiMaggio and Powell 1983), outsourcing adoption may occur because it is a culturally valued phenomenon.

By contrast to the institutional perspective, a large number of studies seek to establish empirically that outsourcing should be adopted for the compelling reason that it produces cost efficiencies. Of course, there may well be other compelling reasons, such as diluting union power, facilitating innovation, and transfer of best practices, but the promise of cost efficiencies is a potent tool for the promotion of outsourcing services in highly competitive cost-conscious organisations.

The following table provides an overview of those studies that substantiate the cost savings argument. The chief proponent of this line of reasoning was the late Simon Domberger, whose work had a major impact, especially in New South Wales during the Greiner government years of the early 1990s. He did most to institutionalise the idea that outsourcing could deliver significant cost savings.

\section{Insert Table 1 about here}

Hodge (1998: 99) concludes, "there is little doubt that the weight of evidence appears to support the notion that, on average, the unit cost of services is reduced through competitive tendering in the public sector". He adds that, yet, 'the often quoted 20\%-savings rhetoric appears to be deceptively optimistic on average and unlikely to apply to many public sector services” (Hodge, 1999: 464). Thus, we may conclude that specific claims to savings may well be substantiated but not to the level that is often claimed by influential commentators such as Domberger. 
The critics of outsourcing argue that efficiency gains are not only much smaller than claimed but that costs increase rather than reduce after services are contracted out (Paddon, 1993; Ganley \& Grahl, 1987; Holcombe, 1991; Walker \& Walker, 2000). The following table summarises some of the main critical arguments.

\section{Insert Table 2 about here}

The critics' main argument is that the realised savings are a result of a redistribution of resources rather that of efficiency gains. Thus, such savings do not generate a net economic benefit; they are, in fact, illusory, when properly accounted for. In general, these authors conclude that outsourcing is not only a fashion but a fashion that does not enhance the performance of the adopting organisations. It has, rather, a negative impact on organisations, as Hunter and Cooksey (2004) argue. After introducing the methodology of our study, we will come back to this finding and show to what extent our study confirms or contradicts it.

\section{RESEARCHING SERVICES OUTSOURCING}

EFM has often been seen as an area in organizations in which employees are able to bargain advantage for themselves. For instance, Crozier's (1964) classic organisational study showed that the maintenance function often represents a residual source of uncertainty in otherwise rationalised systems. As Hickson, Hinings, Lee, Schneck, \& Pennings (1971) were also to claim, control of uncertainty is the key to power in organisations. We may ask whether, if uncertainty about the EFM area can be reduced through outsourcing, bargained advantages will be constrained. If that is the case then there is the potential for costs to be more tightly controlled. Perhaps for this reason, maintenance and facilities are the area of outsourcing that has shown the largest recent growth in recent times.

We can only speculate about the market for outsourcing in Australia, as this is from where our data derives, in which the EFM sector is one of the sectors with the highest percentage of outsourcing contracts. In 2001, BIS Shrapnel estimated the total value of EFM market in Australia at 20 billion AUD, with 44 percent being outsourced (8.8 billion AUD), which makes EFM outsourcing the largest outsourcing area. The latest figures for 2002-2003 indicate that EFM outsourcing sector in Australia has grown 36 percent in the last two years amounting to a total of 12 billion AUD (BIS Shrapnel, 2004). Where EFM has been discussed it is mainly lumped together with other outsourcing areas, such as cleaning services, IT, finance and accounting, legal services etc. (see for example Domberger \& Fernandez, 1999). Only a few studies prior to the present study concentrate exclusively on EFM outsourcing (see for example Bon \& Luck, 1999; Benson \& Ieronimo, 1996; Slater, 1992).

\section{The Study and its Methodologies}

One part of the research was conducted using a postal survey sent to the top fifty customers of one of the major EFM outsourcing providers in Australia. ${ }^{2}$ The contacted customers made

\footnotetext{
2 In Australia, the EFM outsourcing market is dominated, unlike IT and BP outsourcing, by five Australian-owned and based organisations, which are Transfield, Leightons, United Group, Downer EDI and Silcar \& Siemens. In 2003-2004 we received funding from the Australian Research Council Linkage scheme to conduct research into the industry. The linkage scheme encourages researchers to form industry partnerships for the research process, in order to develop research outcomes that are of industry relevance. It is stressed in the ARC guidelines that the research should not be a consultancy. One of the big-five industry companies previously mentioned, Transfield, was our industry partner. We would like to acknowledge the support of the company and its executives. We should stress, however, that our research was conducted independently of the company and was in no way anything other than a dedicated research project.
} 
over 95 percent of the company's $\$ 1$ billion annual turnover and approximately 15 percent of the whole EFM outsourcing market in Australia. It is important to notice that many of the companies contacted did not have outsourcing contracts only with one outsourcing provider, and some of them did not have their primary outsourcing arrangements with this particular provider. Furthermore, the questionnaire asked the customers for their views on their primary outsourcing relationship, which means that some of the responses were related to different outsourcing providers. Thus, although the sample is restricted primarily to the most significant outsourcing organisation in Australasia, it is not exclusively so restricted.

Moreover, this provider represented 15\% of the market share at the time that the research was conducted and was the industry leader. There may thus be some bias as the sample is not randomly stratified but purposive. However, as such it did provide us with unrestricted access to commercially sensitive information that we might well not have been able to access through a less purposive sample.

A ten-page structured questionnaire was compiled and distributed in late 2003. It consisted of 32 questions organised into four broad sections: general information about the respondent company, benefits sought and achieved from outsourcing, with special emphasis on costs; importance of innovation, access to best practice and of contract management, and the respondent's view of the future of their outsourcing arrangements. In this paper, we concentrate on the results that inform us about the benefits of outsourcing and the realised cost savings.

The questionnaire items were developed through a three-fold process ${ }^{3}$. First, we combed the literature for prior concepts that had been used in discussion of outsourcing and either adopted or developed operationalisations of these. Second, we conducted a focus group with a mixture of consultants and service providers at which we presented our initial questionnaire and sought their input in refining its items and in generating items that we might have missed. As a result of the focus group and prior literature review we were able to develop a list of fourteen potential benefits that client organizations might reasonably expect to gain from an outsourcing contract. Thus, we could ask respondents to rank order these as they applied in their particular organization. Third, we then piloted the survey instrument in six outsourcing contracts. The final questionnaire was sent to the selected 50 companies. Twenty-six executives responsible for outsourcing contracts - the contract managers - from 16 different companies completed the questionnaire (a response rate of 52 percent). The outsourcing contracts we investigated, which came from the industry partner, were clearly distinctive: they had different conditions and took place in different companies in different locations. In addition, paired complementary questionnaires were sent to 18 managers from the outsourcing provider company, who were working with the contacted customers (with a response rate of 83 percent). The additional information was analysed and correlated with the customers' responses. Approximately 62 percent of the cases were government organisations, and the remaining 38 percent were from the non-government sector. The sample consisted of rather big organisations, with the smallest one having 40 employees while the largest had approximately 40,000 employees. The average length of the outsourcing relationships we investigated was 4.6 years.

Insert Table 3 about here

In addition to the quantitative survey, five detailed case studies were conducted. Two of the organisations studied were private, from the petroleum and steel industry. The other

\footnotetext{
3 The questionnaire is available on request from the authors.
} 
three were public sector organisations. We used theoretical sampling to choose the cases (Eisenhardt, 1989). The cases were chosen because the data from the questionnaire indicated that these cases demonstrated a high degree of satisfaction with the outsourcing arrangements. Therefore, we wanted to find out what made these outsourcing relationships more satisfactory as well as the issues that were still problematic. In this way, we sought to identify both the most positive case for outsourcing as well as identify what were its weakest links. The case studies explored issues raised by the results of the questionnaire, as well as the history, current status, and likely future of both the contract and outsourcing as it pertained to the organisation.

We sought accounts of how outsourcing worked or did not work for these most successful cases. We used semi-structured interviews and interviewed at least two and sometimes three managers who were directly involved in the outsourcing process from each of the chosen companies. The managers selected were those who could most reasonably be considered to be key informants as far as outsourcing arrangements were concerned: they included managers with overall responsibility for strategic outsourcing, those with responsibility for outsourcing operations and maintenance, and those with operational responsibility for implementation. Two, or occasionally three, researchers were involved in the interviews, with one primarily responsible for the interview and the other for taking notes. In addition to recording notes in writing, the interviews were also tape-recorded and transcribed. The transcriptions of the tapes were corrected, where interpretation was not clear, with the notes that were written in situ. The transcripts were then analysed interpretively to determine the main themes in the interviews. ${ }^{4}$ Interviews typically took 90 minutes, but some lasted several hours. The open-ended approach to interviewing was designed to generate rich accounts of the experience of the managers (Alvesson, 1995) where these accounts are treated as compelling narratives rather than reports of reality (Silverman, 1993).

We began by asking the respondents about the reasons their organisation entered into an outsourcing project; what were the expectations as well as realisation, whether they had been satisfied with the experience, how it compared with the in-house situation that had previously existed. We asked them to describe the advantages of outsourcing for their company, including any unexpected value added. We then asked them to describe any disadvantages that occurred during the current contract period such as decreased staff training and decreased skill level of staff, increased staff turn-over and worsening of the relation between labour and management. The respondents were asked about the roles of communication and culture in the shift to outsourcing. Additionally, they discussed the probable future of the outsourcing contract.

Quantitative findings. There has been considerable growth in EFM outsourcing in the 1990s and our research demonstrated that the primary reason that managers offered for undertaking outsourcing was to reduce costs, with the desired cost savings being between 10 and 20 percent per annum. In this respect, the managers were well primed about the positive claims that have been made in the outsourcing literature - usually primed by the outsourcing providers - and expected to see similar results in their organisations. In most instances managers reported that they required cost savings of at least 10 percent because otherwise the effort involved in using an outside party was not seen to be worthwhile (see also Lacity, Willcocks \& Feeny, 1996). Our quantitative study showed that the average rank for the most

\footnotetext{
${ }^{4}$ We did consider using N.vivo but rejected it as unnecessary given the small number of cases concerned.
} 
important benefit of outsourcing, cost reduction, was nearly 2 whole ranks lower than enhanced reliability, the next most important perceived benefit.

Insert Table 4 about here

Asked about the realised cost savings, 83 percent of the respondents reported that their organisation achieved cost savings as a result of diminished expenditure on people and processes to maintain plant and equipment. The average cost saving delivered to companies was 12.1 percent, but, on average, the top 50 percent of best performing contracts achieved cost savings of 17.9 percent. Therefore, Domberger's projections on cost savings for outsourcing contracts were, on average, replicated in the 26 contracts we analysed. Interestingly, we found no discernable statistical variation in either cost savings or satisfaction between government and private clients. None of the organisations surveyed deemed their contract a failure and 66 percent of the respondents indicated that their experience with the outsourcing provider had exceeded their expectations. Thus, there was little evidence to suggest that outsourcing reduced quality as perceived by the managers of the contracted-out areas.

When respondents were asked about any adverse side effects of outsourcing, only $12 \%$ indicated that the amount of staff training had decreased in comparison to $42 \%$ who stated that it had increased. Similarly, only $29 \%$ answered that staff turnover had increased with 58\% saying that no change occurred. The skill level of the workforce decreased in 15\% of the cases but increased in $42 \%$ of the cases. No case indicated that there had been a worsening of the relation between the outsourced labour force and management compared to the situation prior to outsourcing. Therefore, negative side effects were experienced by some of the surveyed companies but they were by far less than the number of companies where no such negative effects occurred or where improvements were realised.

\section{Insert Figure 1 about here}

As Figure 1 shows, cost savings were derived from initial cost reductions that occurred because of the reduction in payroll, due to reduction of the workforce, as well as from ongoing cost savings achieved through improving the quality of the outsourced workforce by improved training and skill formation as well as the use of better business processes, especially information management. Additionally, idea generation and increased flexibility have been as other sources indicated of cost savings. Often the workforce consisted of rehires of the employees who had previously been in-house providers, but not in every case. For instance, in one case, that of a widely distributed public service organisation, there was no in-house service provision but only highly variable and locally ad hoc arrangements entered into with no centralised control at all. The earliest outsourcing contracts tended to be client/server based, with second-generation contracts often leading to a much closer partnership arrangement. On average survey participants felt a strengthening of the contract from a hands-off to more interactive basis would be beneficial in innovation terms, supporting the view of Gottfredson et al. (2005) that strong third party relationships can improve core management capabilities.

Case Study Findings. As we have stated, to investigate the nature of cost savings in more detail we conducted case studies. The full range of key items that emerged from these case studies are represented, following Miles and Huberman (1994: 128), in Table 5.

Insert Table 5 about here 
We have concentrated on costs and benefits of outsourcing, as seen from the perspective of those who are intimately involved with the outsourcing arrangements in the organizations selected. In our sampling we deliberately sought cases of outsourcing that were as favourable as possible to the thesis that outsourcing represents the emergence of a more efficient approach, using a critical case approach (Flyvbjerg, 2001: 78). That is, we chose those cases where satisfaction with the outsourcing arrangements achieved highest levels.. In Table 5 we focus on the three areas of financial costs, perceived benefits, and unanticipated costs of outsourcing. In what follows we focus on some of these aspects in more detail.

The qualitative study revealed that in pursuing benefits organisations sometimes have to put up with short-term cost increases. Costs often arose during the transitional period as a result of changes aimed at increasing reliability and improving the quality of the maintained assets. The outsourcing provider in one case made clear that not all buildings complied with Occupational Health and Safety standards and uncovered hazards such as lead-based paint and lack of an asbestos hazard register. In another case, the 'how' of maintenance was outsourced while the 'what' and 'when' were retained. With time to plan more efficiently, managers were able to assess maintenance required for the long-term functioning of the machinery. As a result, these improvements generated long-term cost savings through higher reliability and quality of the equipment but in the short-term they caused cost increases. A respondent from this company concluded: "One of the learnings for me [...] was that if I went into this again then we would take a lot more effort to understand what the base was". One of our case study respondents said "to me ... you need to see an alliance not as a oneyear journey or a two-year journey; it is much longer journey to finally extract all the benefits of the alliance".

In the majority of cases, cost savings were achieved together with improvements in the service levels of reliability and quality, indicating that a major shift in efficiency was achieved. The outsourcing contract managers who came into the organisations were specialists in the tasks that they were responsible for rather than being maintenance employees who had been promoted to supervisory posts. Additionally, maintenance employees were no longer regarded as an indirect cost carried in the business of doing something else, such as offering a statutory service or running a major piece of infrastructure. They were now service providers with costs as contracted, which were a predictable expense on the turnover or discharge of the core business, rather than being embedded in the consolidated operating costs of the organisation. The actual costs involved became more transparent, in other words. Where the contacts delivered better results, employees participated in a cost-reduction related incentive scheme. In one client organisation, for example, the normal base load for maintenance and service, including sub-contractors, was 850 people prior to outsourcing. The outsourcing provider's basic payroll was 450 people. More productivity was achieved with fewer people because of improved business processes, more working capital in the form of plant and equipment, and tighter supervising practices. Improved workforce management contributed \$2 million worth of savings in 18 months in one of the companies investigated. The origins of these cost savings were higher levels of accountability of the workforce and a much more transparent performance management plan. In this case, a notoriously militant union plant, outsourcing was introduced on a noredundancy basis, meaning that initial cost cutting was not available.

Respondents sought better solutions through joint access to best practice principles. Noticeable cost savings came from the centralisation of processes that reduced staffing and process costs permanently and at the same time provided centralised means for developing better databases with which organisations could improve maintenance. They did this through increasing the amount of planned preventative maintenance rather than waiting for unplanned breakdown work. One 
respondent from an extremely large and decentralised public sector organisation described the benefits from process centralisation:

"We have never had any detail of what we have done. The only record was we paid someone to do some work. The detail never went onto our system

[...]. But now we have got the detailed invoice that comes in and that is all recorded electronically. So we have got a lot more data than we ever had."

Previously, in this organisation all maintenance decisions had been made independently, locally, with local contractors, without any central cost control, as and when the local managers decided. The discretion available to local managers frequently produced cronyism and other corrupt contracting practices. Thus, costs were enormously variable between locales, the data imprecise, and substantially timelagged. The outsourcing provider instigated an assessment of the condition of the client's 1200 properties across NSW, centralised the invoicing process, put in place a procedure for assuring the statutory compliance of all contractors servicing this client's properties, and established a procedure for preventing use of the maintenance system for properties other than the planned properties. The initial investment of time and money was more than either party had foreseen but the result was decreased processing costs as well as access to rich data that allowed the outsourcing provider to make cost savings through better-informed decision-making. A consistent theme of the case studies was that outsourcing produced much better data and management of data rather than relying on ad hoc and local responses to issues.

One of the managers pointed out that 'productivity, systems improvements and new technology' are basically the main sources of cost reduction. Through cooperation with outside service providers, organisations improved their own processes and structures through introducing outside ideas and new techniques: 'we have more access to more people with different views and different skill sets'. Often, the outsourcing providers became an important source of innovation and organisational change, triggering ongoing cost reductions through new processes. Failure to do this was a major point of dissatisfaction: organisations expected to be 'challenged' with respect to their existing practices. It was anticipated that the outsourcing provider would want to change routines and thus unsettle, or challenge, existing ways of doing things. One of our respondents said 'I always say, 'If you are not challenging us then you are not doing your job' [...] I would like them to challenge us more.'

Sometimes 'challenges' might be quite mundane but effective, nonetheless: a respondent from a large international company reported that the outsourcing provider discovered a new technique to replace water lines with clamp rather than screw fittings, of which they were unaware. That product immediately saved the company $\$ 50,000$. Furthermore, to stimulate more innovation, the company run multi-disciplinary systems improvement programs and projects on maintenance planning involving their outsourcing provider, which gave the provider a forum for introducing challenges to standard practices and processes at the company. In general, the Australian subsidiary of this company moved from being one of the worst performers amongst all international subsidiaries to being one of the best. The success of innovation was judged by improvements in cost reduction and service levels.

\section{Discussion}

To sum up, our research, both qualitative and quantitative, partially confirms Domberger and Fernandez' (1999) estimation of cost savings of around 17-18 percent through EFM outsourcing. Thus, our paper lends support to efficiency arguments as a reason for organisations to adopt outsourcing. At the same time, the unconditional use of the " 20 percent rule” by supporters of contracting out should be criticised. We found, similarly to Hodge 
(1998, 1999), that not all organisations are able to realise cost savings in this range. Outsourcing may be chosen because it is fashionable but still deliver efficiencies.

Substantially, these initial cost savings arise primarily from reductions in the workforce. This confirms Benson and Ieronimo's (1996: 65) findings, which argue that 'the reduction in labour costs caused by having fewer maintenance workers employed on a regular basis was seen by most respondents as an important factor in the decision to outsource'. Workforce reductions are an important source of initial cost savings; in addition, ongoing cost reductions occur through continuous improvements, access to best practice and better workforce management, as suggested by Elmuti, Kathawala, and Monippallil (1998).

The efficiencies gained through outsourcing contracts derive from a number of factors: First, greater control over costs through new disciplines of centralised data collection. Second, this allows for cost-based accounting, and, third, the development of standardised solutions derived from analysis of the data. By creating greater transparency through cost-based accounting, organisations had a better knowledge of the actual costs involved in service delivery.

\section{CONCLUSION}

In terms of the benefits achieved by organisations that outsource services in the EFM sector, our research supports the efficiency arguments of Domberger $(1999,2002)$ and Hodge (1998, 1990). On the magnitude of net savings, the average was $12.1 \%$, which more closely supports Hodges's range of 8-14\% than Domberger's 20\%. Interestingly, Domberger's initial research received particular attention as it focussed on government organisations and agencies. However our research, which covered government and commercial sectors, found no significant statistical variation in cost savings between the two. The results did not support the views of Holcombe (1991) and Walker (2000) that cost reductions had been overestimated.

Our study also found some evidence to support the view that outsourcing was a 'fashion fad' (Benson \& Littler, 2002), but perhaps for different reasons. The means for organisations to outsource service functions were made possible in the mid-1990s with the commercialisation of the web and the development of advanced cost effective digital telecommunications services. At the same time, other digital age developments occurred which created the need. These include the growth of global competition, an increase in productivity, and the need for new skills (Brynjolffson, 2004; Holmes, Burdon, \& Holmes, 2003). From a viewpoint of new management techniques, the companies that switched to outsourcing moved away from a vertically integrated into a co-dependent outsourcing model to develop competitive advantage. In one sense, this change of management practice is a change of fashion, but it is also a development of a more efficient model for dealing with the changing environmental factors of the marketplace. In other words, outsourcing might be a fashion, but a fashion that can bring about positive effects for the outsourcing organisations.

We showed that although outsourcing of services does not guarantee positive results, the vast majority of organisations investigated achieved significant efficiency gains. This research was able to extend the debate in previous publications to show that the magnitude of the savings was closely linked to the success of organisations in developing new management skills to manage outsourcing partners and contracts. This is well illustrated by the fact that the top $50 \%$ of the companies researched achieved cost savings $42 \%$ greater than the average.

\section{REFERENCES}

Abrahamson, E. 1991. Managerial fads and fashions: the diffusion and rejection of innovations. Academy of Management Review, 16(2): 586-612. 
Alvesson, M. 1995. The meaning and meaningless of postmodernism: Some ironic remarks. Organization Studies, 16(6): 1047-1076.

Barthelemy, J. 2001. The hidden costs of IT outsourcing. Sloan Management Review, (Spring): 60-69.

Benson, J., \& Ieronimo, N. 1996. Outsourcing decisions: Evidence from Australia-based enterprises. International Labour Review, 135(1): 59-73.

Benson, J. \& Littler, C. 2002. Outsourcing and workforce reductions: An empirical study of Australian organisations. Asia Pacific Business Review, 8(3): 16-30.

BIS Shrapnel 2001. Maintenance in Australia 2001-2016. North Sydney.

BIS Shrapnel 2004. Maintenance in Australia 2003-2018. North Sydney.

Bon, R., \& Luck, R. 1999. Outsourcing of property-related management functions in Europe and North America, 1993-1998. Construction Management and Economics, 17: 409412.

Boyson, S., Corsi, T., \& Dresner, M. 1999. Managing effective third party logistics relationships: What does it take? Journal of Business Logistics, 20(1): 73-98

Brynjolffson, E. 2004. Productivity's technology iceberg. MIT Technology Review. http://www.technologyreview.com/articles/print_version/wo_brynjolfsson031004.asp. Accessed: 10 March 2004.

Clarke, T., \& Clegg, S. 1998. Management paradigms for the new millennium. International Journal of Management Reviews, 2(1): 45-64.

Crozier, M. 1964. The bureaucratic phenomenon. London: Tavistock.

Cubbin, J., Domberger, S., \& Meadowcroft, S. 1987. Competitive tendering and refuse collection: Identifying the sources of efficiency gains. Fiscal Studies, 8(3): 49-58.

DiMaggio, P., \& Powell, W. 1983. The iron cage revisited: Institutional isomorphism and collective rationality in organizational fields. American Sociological Review, 48: 147160.

Doig, S. J., Ritter, R. C., Speckhals, K., \& Woodson, D. 2001. Has outsourcing gone too far? The McKinsey Quarterly, 4: 24-37.

Domberger, S. 1998. The contracting organization. A strategic guide to outsourcing. Oxford University Press: Oxford.

Domberger, S., \& Fernandez, P. 1999. Public-private partnerships for service delivery. Business Strategy Review, 10(4): 29-39.

Domberger, S., \& Hall, C. 1996. Contracting for public services: A review of antipodean experience. Public Administration, 74: 129-147.

Domberger, S., \& Rimmer, S. 1994. Competitive tendering and contracting in the public sector: A survey. International Journal of the Economics of Business, 1(3): 439-453.

Domberger, S., Fernandez, P., \& Fiebig, D. 1996. Modelling the price and performance of information technology services contracts. Working Paper CTC 03-96, Australian Graduate School of Management, Sydney.

Domberger, S., Hall, C., \& Lik Li, E. 1995. The determinants of price and quality in competitively tendered contracts. The Economic Journal, 105(Nov): 1454-1470.

Domberger, S., Jensen, P., \& Stonecash, R. 2002. Examining the magnitude and sources of cost savings associated with outsourcing. Public Performance \& Management Review, 26(2): 148-168.

Domberger, S., Meadowcroft, S., \& Thompson, D. 1986. Competition and efficiency: The case of refuse collection. Fiscal Studies, 4(4): 69-87.

Domberger, S., Meadowcroft, S., \& Thompson, D. 1988. Competition and efficiency in refuse collection: A reply. Fiscal Studies, 9(1): 86-90.

Eisenhardt, K. 1989. Building theories from case study research. Academy of Management Review, 14(4): 532-550. 
Elmuti, D., Kathawala, Y., \& Monippallil, M. 1998. Outsourcing to gain a competitive advantage. Industrial Management, 40(3): 20-24.

Fischli I. 1996. Outsourcing: a new management tool or just a fad? Bulletin of the American Society for Information Science, 22(4): 20-21.

Flyvbjerg, B. 2001. Making social sciences matter: Why social inquiry fails and how it can succeed again. Cambridge: Cambridge University Press.

Ganley, J., \& Grahl, J. 1988. Competition and efficiency in refuse collection: A critical comment. Fiscal Studies, 9(1): 80-85.

Gilley, M., \& Rasheed, A. 2000. Making more by doing less: An analysis of outsourcing and its effects on firm performance. Journal of Management, 26(4): 763-790.

Gottfredson, M., Puryear, R., \& Phillipos, S. 2005. Strategic sourcing: from periphery to core. Harvard Business Review, 83(2): 132-139

Hickson, D. J., Hinings, C. R., Lee, C. A., Schneck, R. E. \& Pennings, J. M. 1971. A strategic contingencies' theory of intraorganizational power. Administrative Science Quarterly, 16(2): 216-229.

Hodge, G. 1998. Contracting public sector services: A meta-analytic perspective of the international evidence. Australian Journal of Public Administration, 57(4): 98-110.

Hodge, G. 1999. Competitive tendering and contracting out: Rhetoric or reality? Public Productivity \& Management Review, 22(4): 455-469.

Holcombe, R. 1991. Privatisation of municipal wastewater treatment. Public Budgeting and Finance, 11(3): 28-42.

Holmes, J., Burdon, S., \& Terrill, D. 2003. Productivity and organizational transformation: Optimising investment in ICT. National Office of Information Economy, Canberra.

Hunter, J. D., \& Cooksey, R. W. 2004. The decision to outsource: a case study of the complex interplay between strategic wisdom and behavioural reality. Journal of the Australian and New Zealand Academy of Management, 10(2): 26-40.

Hunter, J. D., \& Gates, G. R. 1998. Outsourcing: functional, fashionable, or foolish? In: G. Griffin (Ed.), Management theory and practice: moving to a new era: 133-144. Melbourne: Macmillan.

Lacity, M., Willcocks, L., \& Feeny, D. 1996. The value of selective IT sourcing. Sloan Management Review, (Spring): 13-25.

Lonsdale, C., \& Cox, A. 2000. Rhe historical development of outsourcing: the latest fad? Industrial Management and Data Systems, 100: 444-450.

Macaulay, S. 1966. Law and the balance of power. The automobile manufacturers and their dealers. New York: Russell Sage Foundation.

McDavid, J. 1985. The Canadian experience with privatising residential solid waste collection services. Public Administration Review, 45(5): 602-608.

McEntee, G. 1985. City services: Can free enterprise outperform the public sector? Business and Society Review: 43-47.

Miles, M. B. And Huberman, M. 1994. Qualitative data analysis. Thousand Oaks: Sage.

Paddon, M. 1991. The real costs of contracting out: Re-assessing the Australian debate from UK experience. Discussion Paper No 21, Public Sector Research Centre, University of New South Wales, Sydney.

Paddon, M. 1993. Competitive tendering and contracting out in British local government 1979-1992. Discussion Paper No 30, Public Sector Research Centre, University of New South Wales, Sydney.

Paddon, M. \& Thanki, R. 1995. Submission from Public Sector Research Centre UNSW by M. Paddon and R. Thanki. In M. Paddon \& R. Thanki (Eds.), Australia's contracting 
public services: Critical views of contracting-out by the public sector. Public Sector Research Centre Collected Papers No 2, University of New South Wales, Sydney.

Quiggin, J. 1994. The fiscal gains from contracting out: Transfers of efficiency improvements. Australian Economic Review, (3rd Quarter): 97-102.

Quiggin, J. 1996. Competitive tendering and contracting in the Australian public sector. Australian Journal of Public Administration, 55(3): 49-58.

Rimmer, S. 1994. Competitive tendering and contracting: Theory and research. Australian Economic Review, (3rd Quarter 1994): 79-85.

Rimmer, S. 1998. 'Competitive tendering and outsourcing - initiatives and methods'. Australian Journal of Public Administration, 57(4): 75-84.

Rothery, B. \& Roberts, L. 1995. The truth about outsourcing. Aldershot: Gower.

Savas, E. S. 1993. It's time to privatise. Government Union Review and Public Policy Digest, 14(1): 37-52.

Silverman, D. 1993. Interpreting qualitative data: Methods for analysing talk, text and interaction. London: Sage.

Slater, R. 1992. What's driving the outsourcing bandwagon? Bankers Monthly, 109 (6): 2324.

Walker, R. \& Walker, B. 2000. Privatisation: Sell off or sell out: The Australian experience. ABC Books: Sydney. 
TABLE 1

Supporters of Outsourcing

\begin{tabular}{|l|l|l|}
\hline Key works & Main argument & Main focus \\
\hline $\begin{array}{l}\text { Domberger, Meadowcroft, } \\
\text { \& Thompson, 1986; } \\
\text { Domberger, Meadowcroft } \\
\text { \& Thompson, 1988; } \\
\text { Domberger \& Hall, 1986; } \\
\text { Domberger \& Fernandez, } \\
\begin{array}{l}\text { 1999; Domberger, Jensen } \\
\text { \& Stonecash, 2002 }\end{array}\end{array}$ & $\begin{array}{l}\text { As a result of outsourcing, organisations realise on } \\
\text { decreases in cost. }\end{array}$ & $\begin{array}{l}\text { UK and Australian } \\
\text { public sector }\end{array}$ \\
\hline McDavid (1985) & $\begin{array}{l}\text { Services provided by private companies are 41 } \\
\text { percent less expensive than the same services } \\
\text { offered by public organisations (after controlling } \\
\text { for service levels, scale of output, and environment } \\
\text { factors, and including the contract monitoring } \\
\text { costs). }\end{array}$ & $\begin{array}{l}\text { Canadian public } \\
\text { sector }\end{array}$ \\
\hline Milne (1987) & $\begin{array}{l}\text { Cost savings of an average 44 percent are realised } \\
\text { as a result of outsourcing. }\end{array}$ & $\begin{array}{l}\text { US national health } \\
\text { system }\end{array}$ \\
\hline $\begin{array}{l}\text { Domberger and Rimmer } \\
\text { (1994) }\end{array}$ & $\begin{array}{l}\text { On the average, cost savings of 20 percent per } \\
\text { annum are achieved. }\end{array}$ & $\begin{array}{l}\text { Review of 22 } \\
\text { international } \\
\text { studies on public } \\
\text { sector outsourcing }\end{array}$ \\
\hline Hodge (1998, 1999) & $\begin{array}{l}\text { A cost reduction figure of around 8-14 percent } \\
\text { (without accounting for costs associated with the } \\
\text { outsourcing process) is feasible. }\end{array}$ & $\begin{array}{l}\text { Review of } \\
\text { international } \\
\text { studies on } \\
\text { contracting out in } \\
\text { the public sector }\end{array}$ \\
\hline
\end{tabular}


TABLE 2

Critics of Outsourcing

\begin{tabular}{|l|l|l|}
\hline Key works & Main argument & Main focus \\
\hline Ganley and Grahl (1988) & $\begin{array}{l}\text { Domberger et al. (1986) overestimate the cost } \\
\text { reductions because of a poorly specified cost } \\
\text { equation. Also, important losses that occur as a result } \\
\text { of contracting out are ignored. }\end{array}$ & UK public sector \\
\hline Paddon (1991) & $\begin{array}{l}\text { Outsourcing causes additional costs (for example } \\
\text { management costs in examining and deciding on } \\
\text { tenders), which can outweigh the savings from } \\
\text { contracting out. These costs amount to an average of } \\
\text { 6 percent of the contract value. }\end{array}$ & $\begin{array}{l}\text { UK and Australian } \\
\text { public sector }\end{array}$ \\
\hline $\begin{array}{l}\text { Benson and Ieronimo } \\
\text { (1996); see also }\end{array}$ & $\begin{array}{l}\text { Because of the additional costs associated with } \\
\text { outsourcing, companies need several years to realise } \\
\text { the financial benefits from it. }\end{array}$ & $\begin{array}{l}\text { Australian private } \\
\text { sector }\end{array}$ \\
\hline $\begin{array}{l}\text { Ganley \& Grahl, Gilley } \\
\text { McEntee, 1985; Paddon, } \\
\text { 1991, 1993; Paddon \& } \\
\text { Thanki, 1995; Quiggin, } \\
\text { 1994, 1996; Walker \& } \\
\text { Walker, 2000 }\end{array}$ & $\begin{array}{l}\text { Cost savings often occur at the expense of quality } \\
\text { reductions, deterioration in work conditions, and } \\
\text { employment reductions. }\end{array}$ & $\begin{array}{l}\text { UK and Australian } \\
\text { public sector }\end{array}$ \\
\hline
\end{tabular}


TABLE 3

Survey Respondents

\begin{tabular}{|l|l|l|}
\hline No. of respondents & Industry category & Government vs. private \\
\hline 2 & Food & Private \\
\hline 4 & Petroleum & Private \\
\hline 4 & Steel & Private \\
\hline 1 & Cultural and recreation services & Govt \\
\hline 4 & Defence & Govt \\
\hline 2 & Housing & Govt \\
\hline 2 & Property and business services & Govt \\
\hline 2 & Telecommunications & Govt \\
\hline 2 & Transport & Govt \\
\hline 3 & Utilities & Govt \\
\hline
\end{tabular}


TABLE 4

Pursued Benefits When Undertaking Outsourcing

(With 1 most important and 14 least important)

\begin{tabular}{|lcc|}
\hline Benefits & $\begin{array}{c}\text { Average } \\
\text { rank }\end{array}$ & $\begin{array}{c}\text { Standard } \\
\text { deviation }\end{array}$ \\
Cost reduction & 2.60 & 3.1 \\
Enhanced reliability & 4.40 & 2.2 \\
Improved quality & 4.70 & 2.4 \\
Access to best practice & 5.50 & 2.9 \\
Flexibility & 5.70 & 2.9 \\
Focus on core competences & 5.80 & 3.3 \\
Achieving innovation and continual improvement & 6.00 & 2.6 \\
Catalyst for transformational change & 6.70 & 3.9 \\
Understanding of business' needs and objectives & 7.70 & 3.5 \\
Improving customer relations & 8.60 & 3.2 \\
Improving labour relations & 9.10 & 3.8 \\
Conserving capital & 9.80 & 4.1 \\
Increasing speed to market & 10.4 & 4.1 \\
Other (improving safety performance) & 10.4 & 5.1 \\
\hline
\end{tabular}


FIGURE 1

Sources of Cost Savings

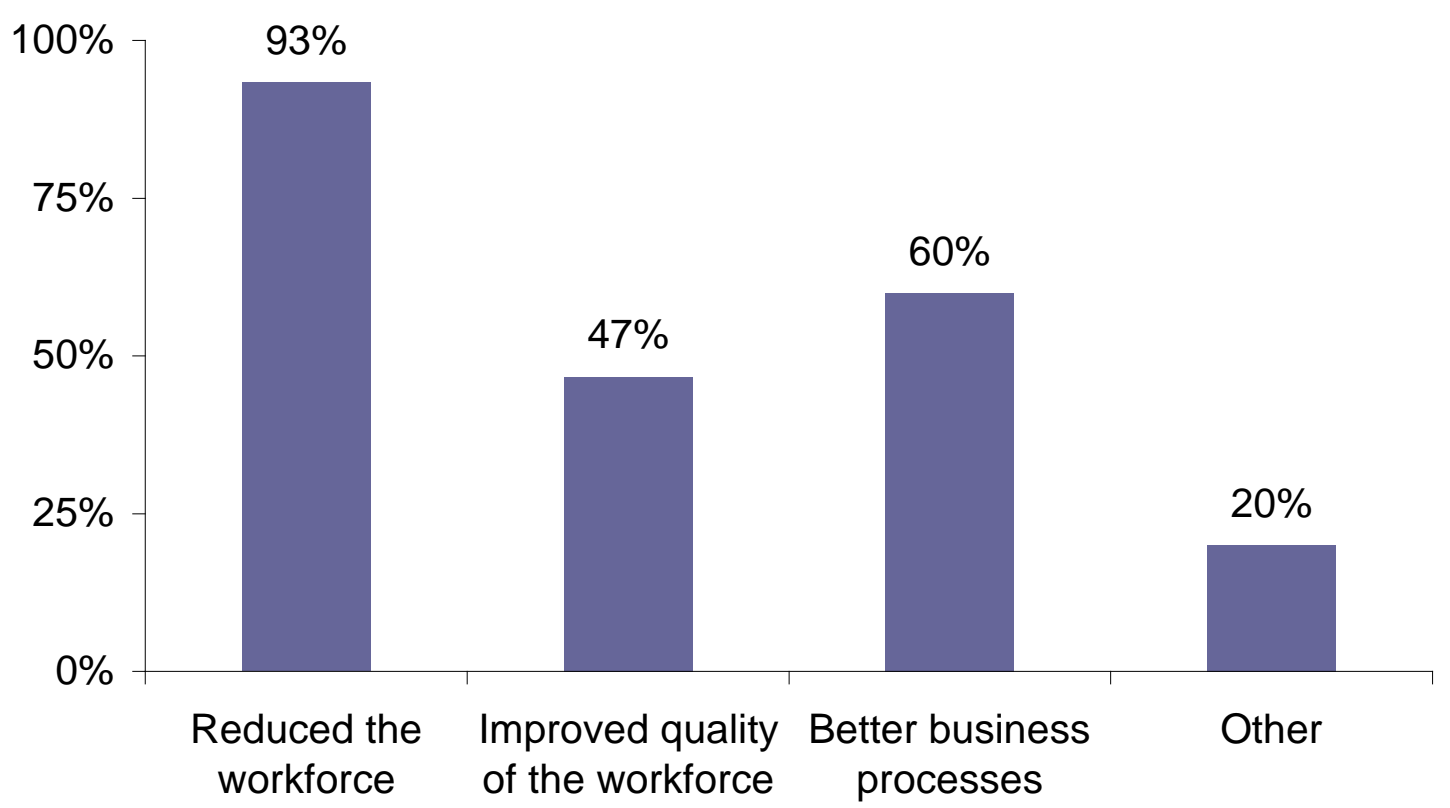


TABLE 5

Case Study Responses to Selected Research Questions

\begin{tabular}{|c|c|c|c|c|}
\hline & & $\begin{array}{l}\text { How has the current contract } \\
\text { reduced costs? }\end{array}$ & $\begin{array}{l}\text { Has there been any unexpected } \\
\text { value add to your business as a } \\
\text { result of E\&FM outsourcing? }\end{array}$ & $\begin{array}{l}\text { Please comment on any } \\
\text { disadvantages }\end{array}$ \\
\hline Organizations & $\begin{array}{l}\text { Respondent and case } \\
\text { details }\end{array}$ & Cost reduction & Unanticipated benefits & Unanticipated costs \\
\hline Organization A & $\begin{array}{l}\text { State-wide Government- } \\
\text { based security } \\
\text { organization; } \\
\text { Manager, Property } \\
\text { Services Branch, } \\
\text { responsible for a large } \\
\text { portfolio of } 350 \text { properties } \\
\text { dotted across the state }\end{array}$ & $\begin{array}{l}\text { Aiming for } 15 \% \text { reduction in costs. } \\
\text { These were achieved through } \\
\text { reduction in overheads by shedding } \\
\text { central office staff by } 75 \% \text {, and } \\
\text { introducing centrally controlled } \\
\text { planned maintenance schedule rather } \\
\text { than local and ad hoc servicing; } \\
\text { cheaper transaction costs for basic } \\
\text { processes such as processing } \\
\text { payments }\end{array}$ & $\begin{array}{l}\text { It can now be guaranteed that all } \\
\text { contractors are properly insured and } \\
\text { appropriately accredited. } \\
\text { Improved OHS by removing lead-based } \\
\text { paints and asbestos from buildings. } \\
\text { New problems that were previously } \\
\text { hidden were revealed through systematic } \\
\text { audit. Compliance with statutory } \\
\text { building code requirements. Using web- } \\
\text { based systems to track progress on } \\
\text { specific maintenance projects and } \\
\text { provide better data on actual problems, } \\
\text { costs, and rectifications. }\end{array}$ & $\begin{array}{l}\text { Making the maintenance work and employees } \\
\text { vulnerable to local criticisms from officials in } \\
\text { the local areas if maintenance was not done as } \\
\text { quickly as would have been the case under the } \\
\text { old local system. Need for constant } \\
\text { communication between central office, field } \\
\text { and the outsourcing company. Problems with } \\
\text { service delivery as service provision is } \\
\text { centralized; criticisms for lack of patronage of } \\
\text { local business and excessive expenditure on } \\
\text { travel costs to bring in contractors. }\end{array}$ \\
\hline Organization B & $\begin{array}{l}\text { Global multinational steel } \\
\text { company; Manager for } \\
\text { Coke \& Coal Plant }\end{array}$ & $\begin{array}{l}\text { Costs were reduced but not self- } \\
\text { evidently so because more and better } \\
\text { service is now being provided, so it } \\
\text { appears as if costs have increased. } \\
\text { Plant now in better shape. The } \\
\text { organization was really quite unclear } \\
\text { about the base-costs before the } \\
\text { contract. }\end{array}$ & $\begin{array}{l}\text { Introducing the contract as an alliance } \\
\text { between the host organization and the } \\
\text { outsourcing company has meant learning } \\
\text { to operate in a new culture. Improved } \\
\text { systems and understanding of how to } \\
\text { implement systems in general. Training } \\
\text { introduced so skill levels enhanced. } \\
\text { Better planning leading to greater } \\
\text { utilization of resources supplied, such as } \\
\text { tradesmen. Better operating procedures } \\
\text { resulting in less need for maintenance } \\
\text { have been learnt as a result of the } \\
\text { outsourcing relation. Lead to a greater } \\
\text { management focus on roles, } \\
\text { expectations, KPIs, and deliverables } \\
\text { through use of SAP system. This }\end{array}$ & $\begin{array}{l}\text { Industrial unrest; strikes; disputes, when the } \\
\text { outsourcing arrangements were first } \\
\text { introduced. Timeliness of service provision } \\
\text { for malfunctioning equipment. Technology } \\
\text { innovations that occur in the host organization } \\
\text { are known to the outsourcing organization and } \\
\text { there is a risk that they may leak to } \\
\text { competitors with whom they also have } \\
\text { outsourcing arrangements. Also, a risk of the } \\
\text { host organization becoming too dependent on } \\
\text { the outsourcing organizations competencies, } \\
\text { capabilities and systems. If the relationship } \\
\text { failed, for some reason, or the outsourcer went } \\
\text { into liquidation, The host organization would } \\
\text { have lost key learning. }\end{array}$ \\
\hline
\end{tabular}




\begin{tabular}{|c|c|c|c|c|}
\hline & & & $\begin{array}{l}\text { produced better data. Also, the } \\
\text { outsourcing organization really knows its } \\
\text { core business - which for our } \\
\text { organization is not core. }\end{array}$ & \\
\hline Organization $\mathrm{C}$ & $\begin{array}{l}\text { Private rail infrastructure } \\
\text { operator; General Manager } \\
\text { and Contract Manager }\end{array}$ & $\begin{array}{l}\text { Seeking } 10 \% \text { savings. Achieved cost } \\
\text { reductions mostly through employing } \\
\text { less people and making those retained } \\
\text { more multi-skilled. Labour costs } \\
\text { were reduced by } 10 \% \text {, saving } \$ 5 \\
\text { million per annum. Labour costs } \\
\text { comprised } 60 \% \text { to } 70 \% \text { of overall } \\
\text { costs. Inventory comprised the } \\
\text { residual. The outsourcing } \\
\text { organization negotiated better } \\
\text { inventory rates; stock turnover; and } \\
\text { better intelligence through a stock list } \\
\text { resulted in } 20 \% \text { savings on inventory. } \\
\text { They were also able to purchase at } \\
\text { more effective rates. Also through } \\
\text { creating a "maintenance culture”, } \\
\text { which, given that maintenance was } \\
\text { not the core business, was lacking. }\end{array}$ & $\begin{array}{l}\text { Lack of initial knowledge about actual } \\
\text { costs; increased clarity about these now } \\
\text { as a result of the outsourcing } \\
\text { arrangement. Achievement of better } \\
\text { practices. A great deal more internal } \\
\text { communication than before when } \\
\text { maintenance was a local affair. The } \\
\text { workforce supervision had improved. } \\
\text { The use of SAP by the host organization } \\
\text { improved as a result of the greater } \\
\text { experience and expertise of the } \\
\text { outsourcing organization. Able to "drill } \\
\text { down” to more and more specific } \\
\text { information. Improved compliance } \\
\text { culture with regulatory environment. } \\
\text { More explicit learning and innovation- } \\
\text { focus throughout the organization. The } \\
\text { introduction of another, more transparent } \\
\text { style of organization culture into the host } \\
\text { organization, from which they were able } \\
\text { to learn. For instance, the "full costs } \\
\text { structure was exposed”. More } \\
\text { engagement with and responsiveness to } \\
\text { the culture of the work force. }\end{array}$ & $\begin{array}{l}\text { "In the transition period the loss of intellectual } \\
\text { knowledge of what to do by the supervising } \\
\text { managers caused perhaps even a deterioration } \\
\text { in compliance ..." } \\
\text { The host organization was so keen to } \\
\text { outsource that it did not do sufficient analysis } \\
\text { and preparation for the transition; this created } \\
\text { considerable expenditure of time and effort } \\
\text { subsequently, as well as "heartache”. } \\
\text { The outsourcing organization did not move as } \\
\text { quickly as expected from reactive to planned } \\
\text { maintenance. The value-additions forecast and } \\
\text { improved business processing had not lived up } \\
\text { to expectations. Less responsiveness to call- } \\
\text { outs and "some things got lost between the } \\
\text { cracks", perhaps as expectations of quality } \\
\text { were greater. Need for more time to be spent } \\
\text { in explicit communication between } \\
\text { outsourcing managers and service users. The } \\
\text { separation of employees in the host } \\
\text { organization but the same union meant that } \\
\text { those who were now employees of the } \\
\text { outsourcing organization gained wage } \\
\text { increases that the host organization employees } \\
\text { did not receive, causing some ill-will and } \\
\text { tension. There was disappointment that the } \\
\text { outsourcing organization had not "injected } \\
\text { new skills and understanding of the industry } \\
\text { or an ability to look at the issues and get } \\
\text { things done”. }\end{array}$ \\
\hline Organization D & $\begin{array}{l}\text { Large multinational oil } \\
\text { refinery; Maintenance } \\
\text { Resource Manager and } \\
\text { Refinery Manager }\end{array}$ & $\begin{array}{l}\text { Costs savings achieved through } \\
\text { improved supervision and } \\
\text { management of equipment. Allows } \\
\text { the organization to focus its } \\
\text { supervisory resources better. }\end{array}$ & $\begin{array}{l}\text { Improved safety and quality systems. } \\
\text { Consistent approach to HR and IR } \\
\text { issues. "Better service ... Its better in the } \\
\text { sense that we have more access to more } \\
\text { people with different views and different }\end{array}$ & Excessive manpower overhead costs. \\
\hline
\end{tabular}




\begin{tabular}{|c|c|c|c|c|}
\hline & & $\begin{array}{l}\text { Expectation of } 2 \% \text { productivity } \\
\text { savings per year. Lower cost structure } \\
\text { of wages, saving } 22 \times \$ 25 \mathrm{~K} \text { per } \\
\text { annum on the wages bill, due to high } \\
\text { industry norms. }\end{array}$ & $\begin{array}{l}\text { skill sets ... they bring things to the table } \\
\text { in terms of challenging us.” } \\
\text { Process innovations, such as replacing } \\
\text { screw-fittings with clamps on water } \\
\text { lines, which saved } \$ 50,000 \text { per annum. } \\
\text { Skill identification and training by } \\
\text { outsourcing organization. Close face-to- } \\
\text { face communication and interaction with } \\
\text { employees through site meetings and } \\
\text { joint meetings with the management of } \\
\text { host organization has resulted in a } \\
\text { greater "realism" and openness to } \\
\text { innovation. }\end{array}$ & \\
\hline Organization E & $\begin{array}{l}\text { State Government } \\
\text { Statutory Authority; } \\
\text { Contract Manager. }\end{array}$ & $\begin{array}{l}\text { The host organization was seeking } \\
\text { 30\% savings. "Fewer people were } \\
\text { used.” }\end{array}$ & None. & $\begin{array}{l}\text { Unions and workforce very unhappy about the } \\
\text { outsourcing arrangements, seven years into } \\
\text { the contract. The contract was so poorly } \\
\text { drawn up that it is difficult to hold the } \\
\text { outsourcing organization to its stipulations - } \\
\text { they are very ill defined. "The source of power } \\
\text { is knowledge and the outsourcing contract } \\
\text { takes away that knowledge." }\end{array}$ \\
\hline
\end{tabular}

